\title{
Simulation and Analysis of Building Energy Consumption in Port passenger Stations
}

\author{
Zheng Xuejing ${ }^{1}$, Sun Qihang ${ }^{1 *}$, Yang Xueqing ${ }^{1}$, Liu Huzhen ${ }^{1}$, Hu Fangshu ${ }^{1}$, Sun Leizhai ${ }^{2}$ \\ 1. School of Environmental Science and Engineering, Tianjin University, Tianjin 300072, China; \\ 2. Contract Management Division, China Overseas Land \& Investment Ltd, Shandong, Qingdao 266011, China
}

\begin{abstract}
Port passenger station buildings (PPSD) are an important part of transportation buildings in China, which is characterized by large human flow, long operating time, high load of equipment and lighting. The characteristics and functions of PPSD lead to the high energy consumption. However, the energy consumption analysis of PPSD was deficient. In this paper, the characteristics of energy consumption of port passenger stations in cold regions and hot summer and warm winter regions in China were analyzed. Based on eQUEST, the building models of port passenger stations are established. The influencing factors of the building energy consumption were analyzed through orthogonal experiment with SPSS. Results show that the factors such as summer indoor design temperature, heat source form, air conditioning form, window to wall ratio and lighting control mode are the key factors affecting the energy consumption of port passenger station.
\end{abstract}

\section{Introduction}

As an important part of public buildings, the traffic architecture has the characteristics of large space span, complex function, large passenger flow and long working time.[1,2,3] A large number of literatures at home and abroad have studied the energy consumption and energy saving potential of transportation hub buildings.

Song et al. [11] investigated the energy consumption of 36 railway stations in north China, and found that the average annual energy consumption per unit area of the high, medium and low grade railway stations was 423 $\mathrm{kWh} / \mathrm{m}^{2}, 222 \mathrm{kwh} / \mathrm{m}^{2}$ and $101 \mathrm{kwh} / \mathrm{m}^{2}$. Huang et al. [12] studied the thermal comfort of the waiting room of a railway station in Harbin. Balaras et al. [13] investigated the energy consumption of 29 airport terminal buildings in three climatic zones in Greece, and obtained that the annual energy consumption per unit area of each climatic zone was $376.0 \mathrm{kWh} /(\mathrm{m} 2 \cdot \mathrm{a}), \quad 244.6 \mathrm{kWh} /(\mathrm{m} 2 \cdot \mathrm{a})$ and $168.3 \mathrm{kWh} /(\mathrm{m} 2 \cdot \mathrm{a})$. Perdamaian et al. [14] use building energy consumption simulation software to analyze Jakarta international airport terminal 3 building annual energy consumption and $\mathrm{CO} 2$ emissions.

There are few studies to analyze energy consumption of port passenger station. Existing studies mainly focus on energy consumption of cargo ports. Wu Peisen [4] discussed the production monitoring method during the construction of the green port in Tianjin Port. Zhang Rongxiang [5] comprehensively analyzed the influencing factors of port energy consumption and constructed the influence factor system of port energy consumption respectively.
At present, there is a lack of research on the energy consumption of port passenger station buildings, and the energy structure and energy consumption of port passenger station buildings in China is still unclear.

In this paper, eight port stations were investigated and tested to obtain the basic information and energy consumption of the port stations. the building models of the port passenger stations are established to analyze the influence factors of the port passenger station through orthogonal experiment.

\section{Energy Consumption Investigation}

\section{1 investigation result}

In this paper, eight port passenger stations were investigated and tested to obtain the basic information and energy consumption of the port passenger stations. There is basic information of the port station recorded in Tab.1. $\mathrm{S} 1 \sim \mathrm{S} 5$ are 5 port passenger stations in cold regions and S6 S8 are 3 port passenger stations in hot summer and warm winter regions. Fig. 1 shows the energy consumption of the port stations.

*sunqihang@tju.edu.cn 
Table1. Basic information of investigated ports

(a) Port stations in cold region

\begin{tabular}{|c|c|c|c|c|c|c|c|}
\hline Port number & $\mathrm{S} 1$ & & S2 & S3 & \multicolumn{2}{|c|}{ S4 } & S5 \\
\hline $\begin{array}{c}\text { Year of } \\
\text { construction }\end{array}$ & 2013 & & 1995 & 2006 & \multicolumn{2}{|c|}{1995} & 2015 \\
\hline $\begin{array}{l}\text { Building area } \\
\qquad(\mathrm{m} 2)\end{array}$ & 40000 & & 7407.8 & 4200 & \multicolumn{2}{|c|}{2930.8} & 6902.2 \\
\hline Stories & 4 & & 5 & 4 & \multirow{2}{*}{\multicolumn{2}{|c|}{$\begin{array}{c}2 \\
\text { South and } \\
\text { north }\end{array}$}} & 2 \\
\hline Orientation & l & & $\begin{array}{l}\text { South and } \\
\text { north }\end{array}$ & $\begin{array}{l}\text { South and } \\
\text { north }\end{array}$ & & & East and west \\
\hline $\begin{array}{l}\text { Daily business } \\
\text { hours (h) }\end{array}$ & \multicolumn{2}{|l|}{15} & 24 & 16 & \multicolumn{2}{|c|}{12} & 14 \\
\hline $\begin{array}{c}\text { Annual } \\
\text { passenger } \\
\text { delivery } \\
\text { volume }\left(\times 10^{4}\right. \\
\text { people })\end{array}$ & \multicolumn{2}{|l|}{85.8} & 113.19 & 47.15 & \multicolumn{2}{|c|}{32.74} & 22.55 \\
\hline $\begin{array}{l}\text { Cold source } \\
\text { form }\end{array}$ & \multicolumn{2}{|c|}{ Water chiller } & $\begin{array}{l}\text { Split air } \\
\text { conditioner }\end{array}$ & $\begin{array}{l}\text { Ground source } \\
\text { heat pump }\end{array}$ & \multicolumn{2}{|c|}{$\begin{array}{l}\text { Split air } \\
\text { conditioner }\end{array}$} & $\begin{array}{c}\text { Air-cooled } \\
\text { water chiller }\end{array}$ \\
\hline $\begin{array}{l}\text { Heat source } \\
\text { form }\end{array}$ & \multicolumn{2}{|c|}{$\begin{array}{l}\text { Municipal hot } \\
\text { water }\end{array}$} & $\begin{array}{l}\text { Split air } \\
\text { conditioner }\end{array}$ & $\begin{array}{l}\text { Ground source } \\
\text { heat pump }\end{array}$ & \multicolumn{2}{|c|}{$\begin{array}{l}\text { Municipal hot } \\
\text { water }\end{array}$} & $\begin{array}{c}\text { Municipal hot } \\
\text { water }\end{array}$ \\
\hline $\begin{array}{c}\text { Air } \\
\text { conditioning } \\
\text { form in the } \\
\text { waiting hall }\end{array}$ & \multicolumn{2}{|c|}{ Fan Coil } & $\begin{array}{l}\text { Split air } \\
\text { conditioner }\end{array}$ & Fan Coil & \multicolumn{2}{|c|}{$\begin{array}{c}\text { Split air } \\
\text { conditioner }\end{array}$} & All air system \\
\hline $\begin{array}{c}\text { Air } \\
\text { conditioning } \\
\text { form in the } \\
\text { offices }\end{array}$ & \multicolumn{2}{|c|}{ Fan Coil } & $\begin{array}{l}\text { Split air } \\
\text { conditioner }\end{array}$ & Fan Coil & \multicolumn{2}{|c|}{$\begin{array}{l}\text { Split air } \\
\text { conditioner }\end{array}$} & Fan Coil \\
\hline $\begin{array}{l}\text { Heating form } \\
\text { in the waiting } \\
\text { hall }\end{array}$ & \multicolumn{2}{|c|}{ Fan Coil } & $\begin{array}{c}\text { Split air } \\
\text { conditioner }\end{array}$ & Fan Coil & \multicolumn{2}{|c|}{ Radiator } & $\begin{array}{l}\text { Radiator } \\
\text { radiates floor } \\
\text { heating }\end{array}$ \\
\hline $\begin{array}{l}\text { Heating form } \\
\text { in the offices }\end{array}$ & \multicolumn{2}{|c|}{ Fan Coil } & $\begin{array}{l}\text { Split air } \\
\text { conditioner }\end{array}$ & Fan Coil & \multicolumn{2}{|c|}{ Radiator } & $\begin{array}{c}\text { Radiator } \\
\text { radiates floor } \\
\text { heating }\end{array}$ \\
\hline \multicolumn{8}{|c|}{ (b) Port stations in hot summer and warm winter region } \\
\hline \multicolumn{3}{|c|}{ Port number } & S6 & \multicolumn{3}{|l|}{ S7 } & S8 \\
\hline \multicolumn{2}{|c|}{ Year of construction } & & 1994 & \multicolumn{3}{|l|}{2015} & 2008 \\
\hline \multicolumn{2}{|c|}{ Building area $(\mathrm{m} 2)$} & & 5620 & \multicolumn{3}{|l|}{6440} & 5223.52 \\
\hline \multicolumn{2}{|c|}{ Stories } & & 2 & \multicolumn{3}{|l|}{2} & 3 \\
\hline \multicolumn{2}{|c|}{ Orientation } & & th and north & \multicolumn{3}{|c|}{ South and north } & th and north \\
\hline \multicolumn{2}{|c|}{ Daily business hours (h) } & & 24 & \multicolumn{2}{|l|}{24} & & 24 \\
\hline $\begin{array}{r}\text { Annual pas } \\
\text { delivery volur } \\
\text { peopl }\end{array}$ & $\begin{array}{l}\text { enger } \\
e\left(\times 10^{4}\right.\end{array}$ & & 293.47 & 251.52 & & & 290.24 \\
\hline Cold sourc & form & Spl & air conditioner & Split air cond & tioner & Split & air conditioner \\
\hline $\begin{array}{l}\text { Air conditionir } \\
\text { the waitin }\end{array}$ & $\begin{array}{l}\text { form in } \\
\text { hall }\end{array}$ & Spl & air conditioner & Split air cond & tioner & Split & air conditioner \\
\hline $\begin{array}{l}\text { Air conditionir } \\
\text { the offi }\end{array}$ & $\begin{array}{l}\text { form in } \\
\text { es }\end{array}$ & Spl & air conditioner & Split air cond & tioner & Split & air conditioner \\
\hline
\end{tabular}




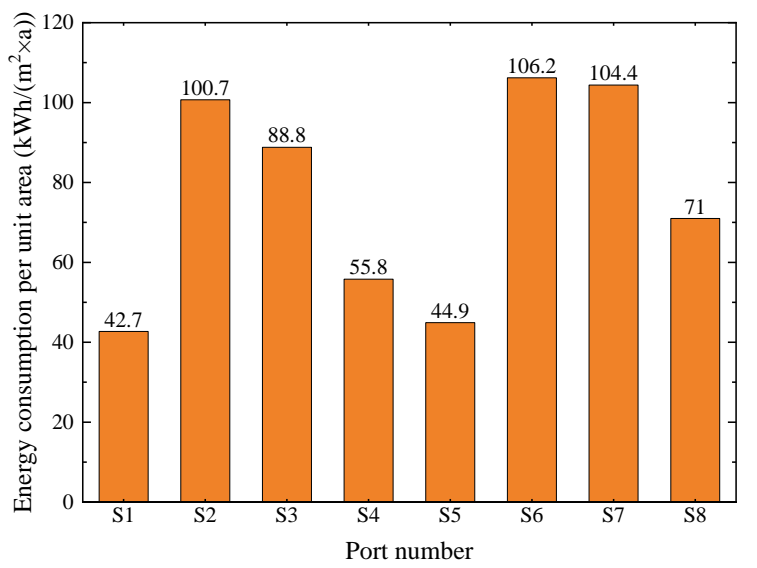

Figure 1. Energy consumption of port stations

As can be seen from Figure 1, there is a big difference in annual comprehensive energy consumption per unit area of port passenger station buildings in cold regions. Among them, S1 and S5 passenger stations use municipal hot water for heating and they are completed later and have better insulation performance of envelope structure, so the annual comprehensive energy consumption per unit area is relatively low. S4 passenger station also uses municipal hot water for heating in winter, but its completion time is earlier, and the insulation performance of the enclosure structure is poor, so the annual comprehensive energy consumption per unit area is higher than $\mathrm{S} 1$ and $\mathrm{S} 5$, while $\mathrm{S} 2$ and $\mathrm{S} 3$ passenger stations all use electricity for heating, so the comprehensive energy consumption is much higher than S1, S4 and S5.

Compared with the cold region, the difference of annual energy consumption per unit area of port passenger station building in hot summer and warm winter is relatively small. S8 passenger station has the lowest annual comprehensive energy consumption per unit area, which is due to the later completion time, good insulation performance of the envelope structure, and the use of energy-saving lamps, so the lighting energy consumption is low.

The comprehensive energy consumption per unit area of port passenger stations in cold regions ranges in $42.70 \sim 153.26 \mathrm{kWh} /\left(\mathrm{m}^{2} \cdot \mathrm{a}\right)$, with an average of $81.02 \mathrm{kWh} /(\mathrm{m} 2 \cdot \mathrm{a})$. The comprehensive energy consumption per unit area of port passenger stations in hot summer and warm winter regions ranges in $71.05 \sim 106.19 \mathrm{kWh} /\left(\mathrm{m}^{2} \cdot \mathrm{a}\right)$, with an average of $93.86 \mathrm{kWh} /(\mathrm{m} 2 \cdot \mathrm{a})$.

\subsection{Thermal environment and comfort test}

In this paper, the Port S2 and S7 are selected for the thermal comfort survey. Results of thermal environment data of the waiting hall are shown in Tab. 1 and Tab. 2 .

Table2. Thermal environment test

(a) Port S2

\begin{tabular}{|c|c|c|c|c|c|c|}
\hline \multicolumn{5}{|c|}{ Indoor air parameters } & \multicolumn{2}{|c|}{ Outdoor air parameters } \\
\hline & $\begin{array}{c}\text { Temperature } \\
\left({ }^{\circ} \mathrm{C}\right)\end{array}$ & $\begin{array}{c}\text { Relative } \\
\text { humidity } \\
(\%)\end{array}$ & $\begin{array}{c}\text { Radiation } \\
\text { temperature } \\
\left({ }^{\circ} \mathrm{C}\right)\end{array}$ & $\begin{array}{c}\text { air } \\
\text { velocity } \\
(\mathrm{m} / \mathrm{s})\end{array}$ & $\begin{array}{c}\text { Temperature } \\
\left({ }^{\circ} \mathrm{C}\right)\end{array}$ & $\begin{array}{c}\text { Relative } \\
\text { humidity } \\
(\%)\end{array}$ \\
\hline Maximum & 27.17 & 62.15 & 29.51 & 0.15 & 37.49 & 86.44 \\
\hline Minimum & 25.74 & 55.49 & 25.71 & 0.01 & 27.47 & 58.02 \\
\hline Average & 26.32 & 58.22 & 27.22 & 0.05 & 33.63 & 71.53 \\
\hline \multicolumn{7}{|c|}{ (b) Port S7 } \\
\hline & \multicolumn{3}{|c|}{ Indoor air parameters } & \multicolumn{3}{|c|}{ Outdoor air parameters } \\
\hline & $\begin{array}{c}\text { Temperature } \\
\left({ }^{\circ} \mathrm{C}\right)\end{array}$ & $\begin{array}{c}\text { Relative } \\
\text { humidity } \\
(\%)\end{array}$ & $\begin{array}{c}\text { Radiation } \\
\text { temperature } \\
\left({ }^{\circ} \mathrm{C}\right)\end{array}$ & $\begin{array}{c}\text { air } \\
\text { velocity } \\
(\mathrm{m} / \mathrm{s})\end{array}$ & $\begin{array}{c}\text { Temperature } \\
\left({ }^{\circ} \mathrm{C}\right)\end{array}$ & $\begin{array}{c}\text { Relative } \\
\text { humidity } \\
(\%)\end{array}$ \\
\hline Maximum & 28.41 & 63.59 & 29.53 & 0.19 & 40.88 & 91.98 \\
\hline Minimum & 25.89 & 52.35 & 27.29 & 0.01 & 30.96 & 60.51 \\
\hline Average & 26.85 & 56.09 & 28.17 & 0.04 & 36.31 & 75.33 \\
\hline
\end{tabular}

According to the thermal comfort survey results, the linear regression line between the average thermal sensation vote (MTS) of port passenger station and the operating temperature was obtained by fitting, as shown in Figure 2. The thermal neutral temperature in the waiting hall of S2 passenger station was $26.7^{\circ} \mathrm{C}$, close to the average temperature of $26.32^{\circ} \mathrm{C}$ in the test area, indicating that passengers were comfortable with the thermal sensation in the waiting hall. The thermal neutral temperature in the waiting hall of $\mathrm{S} 7$ passenger station was $27.5^{\circ} \mathrm{C}, 0.65^{\circ} \mathrm{C}$ higher than the average temperature in the test area, indicating that the thermal sensation of passengers to the waiting hall was slightly warmer. The results were consistent with the thermal sensation voting results of passengers.

The thermal sensation voting values within $-1 \sim+1$ were regarded as satisfaction with the thermal environment. The passenger satisfaction rate within each temperature range is calculated, and the quadratic equation regression is obtained, as shown in Fig.3. The thermal environment with $80 \%$ satisfaction rate is defined as comfort environment. The acceptable temperature ranges for passengers in the waiting hall of Port S2 and S7 are $25.6 \sim 27.9^{\circ} \mathrm{C}$ and $26.8 \sim 28.8^{\circ} \mathrm{C}$, respectively. 


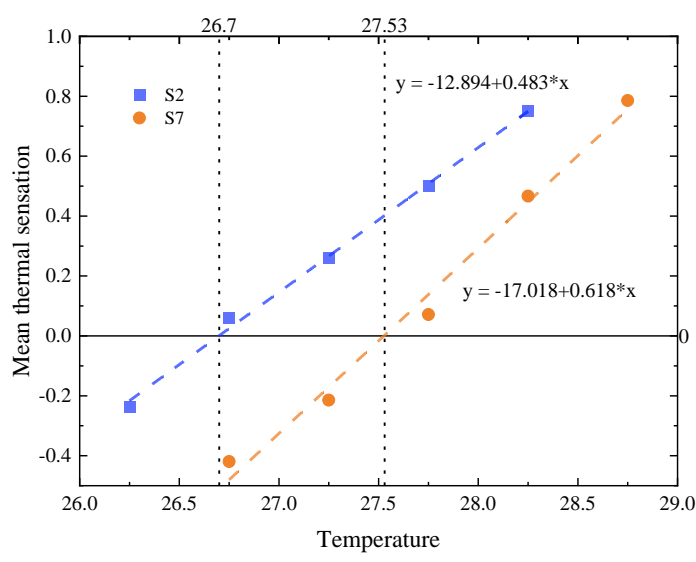

Figure 2. Mean thermal sensation

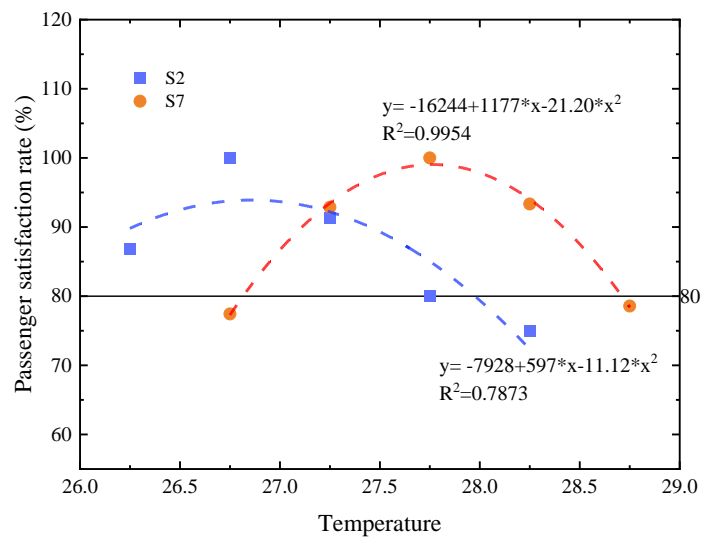

Figure 3. Passenger satisfaction rate

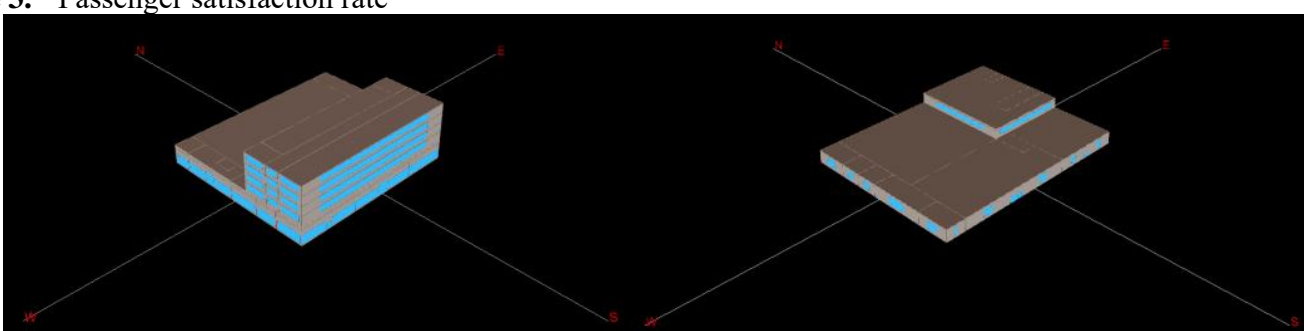

(a) Port S2

Figure 4. Building Models of S2 and S7

The building model of S2 passenger station has 5 floors above ground, with a north-south orientation, a building size coefficient of 0.196 , and a total area of 73,48 $\mathrm{m}^{2}$. The building model of S7 passenger station has 2 floors above the ground, with a north-south orientation, a building size coefficient of 0.19 , and a total passenger station area of $6200 \mathrm{~m}^{2}$. The density of personnel is calculated by passenger transport volume, daily ship times and waiting hall area of passenger station. The lighting power density is selected according to the actual situation. The power density of equipment refers to the Public Building Energy Conservation Design Standard [8].

The heating period of S2 passenger station is from November 15 to March 15 of the next year, and the cooling period is from June 15 to September 30 . Air conditioning system is used for heating and cooling. The air conditioning system adopts the separated type air conditioner. S7 passenger station operates all day. The cooling period of the building is set from April 15 to November 15, and there is no heating period. The air conditioning system also
The temperature acceptance range of passengers in the waiting hall of port passenger stations is large, which is due to the adaptability and tolerance of passenger to the waiting thermal environment of ports. The actual temperature in the waiting hall of the two ports is lower than the thermal neutral temperature. The indoor temperature in the waiting hall can be improved appropriately to reduce the energy consumption of air conditioning.

\section{Simulation}

\subsection{Building model}

Using eQUEST, the building model of Port S2 in cold region and Port $\mathrm{S} 7$ in hot summer and warm winter region are established[6,7], as shown in Figure 4. adopts the separated type air conditioner, and the interior design temperature is $26^{\circ} \mathrm{C}$.

\subsection{Results and validation of simulation}

The simulation results show that the annual total energy consumption of $\mathrm{S} 2$ port passenger station model is $719,290 \mathrm{kwh}$, among which heating and air conditioning energy consumption is the highest, accounting for $53 \%$ of the total energy consumption, electrical equipment energy consumption is the second, accounting for $35 \%$, lighting system energy consumption is the lowest, but still accounting for $12 \%$. The total annual energy consumption of S7 port passenger station is $6,886,70 \mathrm{kwh}$, among which the energy consumption of air conditioning system is the highest, accounting for $37 \%$ of the total energy consumption. The energy consumption of electrical equipment and lighting system is similar, accounting for $30 \%$ and $33 \%$ of the total energy consumption respectively. The comparison between model results and actual survey data is shown in Tab. 3. 
Table3. Simulation results and model verification

\begin{tabular}{lccccc}
\hline & Lighting & Equipment & Cooling & Heating & Total \\
\hline $\begin{array}{c}\text { Simulated result } \\
\left(\times 10^{3} \mathrm{kWh}\right)\end{array}$ & 85.70 & 250.51 & 95.49 & 287.58 & 719.28 \\
$\begin{array}{c}\text { Measured result } \\
\left(\times 10^{3} \mathrm{kWh}\right)\end{array}$ & 84.97 & 261.98 & 97.49 & 301.57 & 746.01 \\
Relative error & $0.86 \%$ & $-4.38 \%$ & $-2.05 \%$ & $-4.64 \%$ & $-3.58 \%$ \\
\hline
\end{tabular}

(b) Port S7

\begin{tabular}{rcclc}
\hline & Lighting & Equipment & Cooling & Total \\
\hline $\begin{array}{r}\text { Simulated result } \\
\left(\times 10^{3} \mathrm{kWh}\right)\end{array}$ & 227.57 & 205.07 & 256.03 & 688.67 \\
$\begin{array}{r}\text { Measured result } \\
\left(\times 10^{3} \mathrm{kWh}\right)\end{array}$ & 226.04 & 210.72 & 235.25 & 672.02 \\
Relative error & $0.68 \%$ & $-2.68 \%$ & $8.83 \%$ & $-2.48 \%$ \\
\hline
\end{tabular}

The relative error of the total energy consumption is less than 5\%, and the maximum relative error of each item of energy consumption is within $10 \%$. which indicates that there is a good agreement between the simulated result and the actual energy consumption.

\section{Orthogonal test method}

\subsection{Orthogonal test}

Orthogonal test design is a kind of method of analyzing the multiple factors. According to the test factors, the number of levels and the interaction among the factors, the orthogonal table is designed. Relying on the orthogonality of orthogonal table, the typical experiment points are selected for experiments, which greatly reduces the number of experiments. The application of orthogonal test table design is a kind of efficient, fast and economic method of multifactor experimental design.

\subsection{Design of orthogonal test}

Table 4 list the influence factors and their horizontal values[8]. SPSS software is used to generate the orthogonal table and analyze the results of orthogonal test $[9,10]$.

Table4. Influence factors and level values

(a) Port in cold region

\begin{tabular}{|c|c|c|c|}
\hline Influence factors & Level 1 & Level 2 & Level 3 \\
\hline Roof heat transfer coefficient $\left(\mathrm{W} /\left(\mathrm{m}^{2} \cdot \mathrm{K}\right)\right)$ & 0.35 & 0.45 & 0.55 \\
\hline Wall heat transfer coefficient $\left(\mathrm{W} /\left(\mathrm{m}^{2} \cdot \mathrm{K}\right)\right)$ & 0.40 & 0.50 & 0.60 \\
\hline Window heat transfer coefficient $\left(\mathrm{W} /\left(\mathrm{m}^{2} \cdot \mathrm{K}\right)\right)$ & 2.1 & 2.3 & 2.5 \\
\hline Window shading coefficient & 0.36 & 0.40 & 0.43 \\
\hline Window wall ratio & 0.4 & 0.5 & 0.6 \\
\hline Lighting power density $\left(\mathrm{W} / \mathrm{m}^{2}\right)$ & 5 & 6 & 7 \\
\hline Equipment power density $\left(\mathrm{W} / \mathrm{m}^{2}\right)$ & 8 & 10 & 12 \\
\hline Heating design temperature $\left({ }^{\circ} \mathrm{C}\right)$ & 18 & 20 & 22 \\
\hline Cooling design temperature $\left({ }^{\circ} \mathrm{C}\right)$ & 25 & 26 & 27 \\
\hline Frequency conversion control & $\mathrm{Y}$ & $\mathrm{N}$ & l \\
\hline \multicolumn{4}{|c|}{ (b) Port in hot summer and warm winter region } \\
\hline Influence factors & Level 1 & Level 2 & Level 3 \\
\hline Roof heat transfer coefficient $\left(\mathrm{W} /\left(\mathrm{m}^{2} \cdot \mathrm{K}\right)\right)$ & 0.3 & 0.4 & 0.5 \\
\hline Wall heat transfer coefficient $\left(\mathrm{W} /\left(\mathrm{m}^{2} \cdot \mathrm{K}\right)\right)$ & 0.6 & 0.8 & 1 \\
\hline Window heat transfer coefficient $\left(\mathrm{W} /\left(\mathrm{m}^{2} \cdot \mathrm{K}\right)\right)$ & 2 & 2.5 & 3 \\
\hline Window shading coefficient & 0.6 & 0.7 & 0.8 \\
\hline Lighting power density $\left(\mathrm{W} / \mathrm{m}^{2}\right)$ & 5 & 6 & 7 \\
\hline Equipment power density $\left(\mathrm{W} / \mathrm{m}^{2}\right)$ & 8 & 10 & 12 \\
\hline Cooling design temperature $\left({ }^{\circ} \mathrm{C}\right)$ & 26 & 27 & 28 \\
\hline Frequency conversion control & $\mathrm{Y}$ & $\mathrm{N}$ & / \\
\hline
\end{tabular}




\subsection{Results}

The building model is used to simulate the building energy consumption of the port passenger station model under

different parameters. SPSS software was used to analyze the results of the orthogonal test to determine the significance levels of each factor of total energy consumption of the buildings of the port passenger station. The results are shown in Tab.5.

Table5. Orthogonal experimental analysis of variance

\begin{tabular}{|c|c|c|c|}
\hline \multicolumn{2}{|l|}{ S2 } & \multicolumn{2}{|l|}{ S7 } \\
\hline Influence factors & $\mathrm{F}$ & Influence factors & $\mathrm{F}$ \\
\hline Roof heat transfer coefficient & 58 & Roof heat transfer coefficient & 15 \\
\hline Wall heat transfer coefficient & 12 & Wall heat transfer coefficient & 7 \\
\hline $\begin{array}{l}\text { Window heat transfer } \\
\text { coefficient }\end{array}$ & 17 & $\begin{array}{l}\text { Window heat transfer } \\
\text { coefficient }\end{array}$ & 5 \\
\hline Window shading coefficient & 1 & Window shading coefficient & 268 \\
\hline Window wall ratio & 214 & Lighting power density & 4077 \\
\hline Lighting power density & 76 & Equipment power density & 16534 \\
\hline Equipment power density & 148 & Cooling design temperature & 7549 \\
\hline Frequency conversion control & 538 & Frequency conversion control & 12487 \\
\hline Heating design temperature & 1013 & & \\
\hline Cooling design temperature & 39 & & \\
\hline
\end{tabular}

According to the results of $\mathrm{F}$ test, the ranking of significance of the total energy consumption impact factors can be obtained:

Cold area: heating design temperature $>$ frequency conversion control $>$ window wall ratio $>$ equipment power density $>$ lighting power density $>$ roof heat transfer coefficient $>$ cooling design temperature $>$ window heat transfer coefficient $>$ wall heat transfer coefficient $>$ window shading coefficient.

Hot summer and warm winter area: equipment power density $>$ frequency conversion control $>$ cooling design temperature $>$ lighting power density $>$ window shading coefficient $>$ roof heat transfer coefficient $>$ wall heat transfer coefficient $>$ window heat transfer coefficient.

\section{Conclusion}

(1) The investigation shows that the port passenger station buildings have the characteristics of long operation time, large fluctuation of energy consumption and high building energy consumption. The average comprehensive energy consumption per unit area of investigated port passenger stations in cold regions and hot summer and warm winter regions are $81.02 \mathrm{kWh} /\left(\mathrm{m}^{2} \cdot \mathrm{a}\right)$ and $93.86 \mathrm{kWh} /(\mathrm{m} 2 \cdot \mathrm{a})$, respectively.

(2) The result of thermal comfort test indicates that appropriately lowering indoor temperature can reduce the energy consumption of air conditioning and buildings.

(3)By analyzing the results of orthogonal experiment, the ranking of factors of building energy consumption is obtained, which can provide ideas for energy saving of port buildings.

\section{Acknowledgement:}

This work was supported by National Key R\&D Program of China (grant number 2018YFC0705000)

\section{Reference}

1. Huang Haijun. Analysis of the main characteristics of traffic buildings in China[J]. Architectural Engineering Technology and Design, 2016, (16): 
1175. (in Chinese)

2. Wei Qingfan, Wang Xin, Xiao He, et al. Current situation and features of energy consumption of Chinese public buildings[J]. Controduction Science and Technology, 2009, (08): 38-43. (in Chinese)

3. Zhang Yijun. About humanized design for airport terminal: taking Hongqiao transportation hub T2 terminal as example[j]. Architectural Journal, 2010, (11): 101-105. (in Chinese)

4. Wu Peisen, Kang Zhongfei. Review of energy consumption monitoring of a container terminal in Tianjin Port[J]. Journal of Green Science and Technology, 2018,12:183-189. (in Chinese)

5. Zhang Rongxiang. Construction of influencing factor system of port energy consumption[J]. Journal of Green Science and Technology, 2017,4:111-112. (in Chinese)

6. Ma Xiaoyun. Building energy consumption simulation software eQUEST and its application[J]. Building Energy \& Environment, 2009, 8(6): 7780. (in Chinese)

7. Wang Weihan. Analysis of energy saving measures of low-rise residential building based on eQUEST. Architecture Technology, 2018，49(12): 1300-1303.

8. Lu Zhiqiang. Research on the influencing factors of energy consumption for Tianjin residential buildings[D]. School of Environmental Science and Engineering, Tianjin University, 2012. (in Chinese)

9. Wang Donghua. Multivariate statistical analysis and SPSS application[M]. Shanghai: East China University of Science and Technology Press, 2018: 83-84.

10. Xie Yanqun. Investigation and measurement of residential energy consumption in Changsha and statistical analysis of its influencing factors[D]. Hunan university, 2007. (in Chinese)

11. Ling Song, Ying Wang, Xiaofeng Li. Energy performance and environmental quality of typical railway passenger stations in northern China [J]. Indoor and built environment, 2018, 27(03): 296-307.

12. Meng Huang, Yujie Lin. Thermal comfort of railway station's waiting room in severe cold regions of China [J]. Energy Procedia, 2017,134:749-756.

13. C.A. Balaras, E. Dascalaki, A. Gaglia, K. Droutsa. Energy conservation potential, HVAC installations and operational issues in Hellenic airports [J]. Energy and Buildings, 2003,35:1105-1120.

14. Laksana Gema Perdamaian, Rachmawan Budiarto, Mohammad Kholid Ridwan. Scenarios to Reduce Electricity Consumption and $\mathrm{CO} 2$ Emission at Terminal 3 Soekarno-Hatta International Airport [J]. Procedia environment sciences, 2013, 17:576-585. 